УДК 930. $1(470+571): 141.82$

ББК 63.1(2)5-82

\title{
М.И. ТУГАН-БАРАНОВСКИЙ И ЕГО ОТНОШЕНИЕ К МАРКСИЗМУ ${ }^{1}$
}

\author{
Туган-Барановский Джучи Михайлович \\ Доктор исторических наук, профессор кафедры археологии и зарубежной истории \\ Волгоградского государственного университета \\ adsi@volsu.ru \\ Проспект Университетский, 100, 400062 г. Волгоград, Российская Федерация
}

Аннотация. В статье оспаривается распространенная в советской литературе точка зрения, что М.И. Туган-Барановский изначально не был марксистом. Прослеживается в работах этого мыслителя путь от искреннего увлечения марксизмом до открытой критики и обвинения марксизма в социальном монизме, абсолютизации роли производительных сил в историческом процессе, недооценке психических факторов общественного развития, до отрицания сформулированного К. Марксом закона тенденции нормы прибыли к понижению. Кроме того, отмечена резкая критика русским ученым марксизма с этических позиций и предвидение в критике марксистской этики и морали ленинизма и сталинизма. Также делаются выводы о его вкладе в историю общественной мысли, о поиске им в начале XX в. своего пути, на котором было мало принципиальных соприкосновений с марксизмом.

Ключевые слова: марксизм, ревизионизм, социализм, народники, теория кризисов, «легальный марксизм».

В России и СССР работы М.И. ТуганБарановского переиздавались неоднократно до 1938 года. В 1938 г. в Москве вышло 7-е издание его «Русской фабрики». Потом наступил длительный период забвения, который продолжался до 1989 года. В советское время М.И. Туган-Барановский оценивался крайне отрицательно в различных энциклопедиях и справочных изданиях. Например, в «Советском энциклопедическом словаре» (1983) гово-

Иванович (1865-1919) - русский экономист,

$\sum$ историк, один из представителей «Легально-

ז го марксизма», впоследствии открытый за-

щитник капитализма. В конце 1917-го - янва-

。̊. pe 1918 гг. - министр финансов контрреволю-

๘ ционной Центральной рады» [18, с. 693]. Ана-

气ึ логичная оценка в «СЭС» давалась и «легаль-

ному марксизму», представителям буржуазно-

今 го либерализма [там же]. Подобным образом

(?) оценивался М.И. Туган-Барановский и в «Ук- раинской советской энциклопедии» (1984) [35, с. 380 ], и в различных исторических и экономических исследованиях [4; 37]. Должен сказать, что в 30-50-егг. XX в. определенные проблемы возникали у его сына - М.И. Туган-Барановского. Ему, опытному и известному журналисту, «не рекомендовали» публиковаться под своей полной фамилией, и он часто подписывался только «М. Туган». В 1966 г. в саратовском журнале «Волга» (в № 9-11) должны были выйти его воспоминания. Но в последний момент уже готовый № 8 по указанию местного обкома КПСС был рассыпан и были запрещены остальные номера на том основании, что мой отец «вспоминает» своего отца иначе, чем о последнем писал В.И. Ленин. Мне доподлинно известно, что об этом была составлена специальная записка авторитетного чиновника обкома партии.

Сейчас, когда уже пали идеологические запреты, было бы важно объективно выяснить 
подлинное отношение М.И. Туган-Барановского к марксизму и социализму.

Прежде всего, нужно сказать, что М.И. Туган-Барановский не был вполне ортодоксальным марксистом, хотя до 1899 г. его разногласия с марксизмом проявлялись в довольно завуалированной форме. Он, например, использовал первый и второй тома «Капитала» К. Маркса в своей магистерской работе, посвященной промышленным кризисам (1894), а его труд «Русская фабрика» (1898) был основан на марксистской методологии.

Девяностые годы девятнадцатого века, особенно их середина, были своеобразным переломным временем, когда в студенческих аудиториях, в квартирах интеллигентов, на заседаниях Императорского Вольно-экономического общества и на страницах журналов шли ожесточенные споры между марксистами и народниками. Дискуссии принимали порой настолько яростный характер, что это сказывалось на личных отношениях споривших. Нередко заседания кончались потасовками. Н.И. Кареев, видный историк, рассказывал в своих воспоминаниях, что однажды после бурного заседания к нему пришел за советом студент-первокурсник: дескать, он не знает, кем ему быть, марксистом или народником, а быть и тем и другим студенту-де нельзя. Тогда Н.И. Кареев, в общем тяготевший к народникам, сослался на то, что он ни то, ни другое. Студент в ответ заявил: «Вам можно - вы профессор, а вот нашему брату нельзя» [6, с. 195].

В этой борьбе М.И. Туган-Барановский вместе со своим тогда единомышленником и другом П.Б. Струве был на стороне марксистов. Тот же Н.И. Кареев писал, что на заседаниях Петербургского исторического общества М.И. Туган-Барановский и П.Б. Струве «были просто идолами одной части слушателей», тогда как их оппоненты - идолами другой [там же].

В ту пору М.И. Туган-Барановский и П.Б. Струве в марксистской среде, особенно в Петербурге, по популярности, вероятно, опережали других. «Вначале, - вспоминала А. Тыркова-Вильямс, - об Ульянове (Ленине. - Авт.) говорили мало. На поверхности петербургского марксизма, на глазах у всех, включая Департамент полиции, бушевали два молодых вожака - Струве и Туган... Они были неразлучны, вместе давали они битвы в полузакрытых собраниях Императорского Вольно-экономического общества... Эти два Аякса марксизма вместе составляли программы и манифесты, явные и тайные, вместе затевали и губили журналы, вместе шли приступом на народников...» [34, с. 34-35].

Отзвуки петербургских дискуссий находили отклик в других городах. «До нас, московских студентов-марксистов, - писал уже в середине XX в. выдающийся русский философ С.Л. Франк, - доходили в 1894-1896 гг. вести о шумных выступлениях П.Б. Струве (вместе с М.И. Туган-Барановским) в схватках с народниками в Петербурге, на студенческих вечеринках и в заседаниях научных обществ» [36, c. 15]. Будущий известный социал-демократ Н. Валентинов, перешедший затем на меньшевистские позиции, писал в своих воспоминаниях, что на него большое впечатление произвели работы М.И. Туган-Барановского «Русская фабрика» и П.Б. Струве «Критические заметки к вопросу об экономическом развитии России». Эти работы показались Н. Валентинову «более интересными», чем книга В.И. Ленина «Развитие капитализма в России» [2, с. 49]. Он также сообщает в мемуарах, что его, в 18971898 гг. студента Технологического института в Петербурге, «ввел... в марксизм и не переставал потом толкать на изучение экономики» именно Михаил Иванович» [там же, с. 73]. Очевидно, определенное влияние М.И. Туган-Барановского испытали также болгарский революционер Х. Раковский, В. Поссе и др.

По словам А. Тырковой-Вильямс, в середине 90-х гг. М.И. Туган-Барановский, как и П.Б. Струве, искренне и безоговорочно верил в марксизм и его творческую силу. Они могли наизусть цитировать К. Маркса и Ф. Энгельса, твердить марксистские истины, как говорит А. Тыркова-Вильямс, «с послушным упорством мусульманина, проповедующего Коран». Они, далее продолжает мемуаристка, были совершенно уверены, что правильно приведенное изречение из «Капитала» или даже из переписки с Марксом и Энгельсом разрешает все сомнения и споры. «А если еще указать, в каком издании и на какой странице это напечатано, то возражать могут только идиоты. Для этих начетчиков марксизма каж- 
дая буква в сочинениях Маркса и Энгельса была священна. Слушая их, я поняла, как мусульманские завоеватели могли сжечь Александрийскую библиотеку» $[34$, с. 36].

А. Тыркова-Вильямс говорит о себе, что она скептически относилась к марксизму, хотя и мало читала о нем. Но Туган-Барановский произносил яростные монологи в защиту этой теории: «Неужели вы воображаете, что через 30 лет в Европе еще будет существовать частная собственность? Конечно, нет! Пролетариат все это сметет. Исчезнет к тому времени и полицейское государство. Все будут свободны. Не забывайте, что люди учатся летать. При развитии авиации полицейское государство не может существовать. Воздух не знает ни границ, ни паспортов» [там же, с. 42].

«Эти слова, - говорит А. Тыркова-Вильямс, - мне крепко запомнились. Доживи Туган до наших дней, он увидел бы, что самые жестокие формы полицейского государства существуют именно в социалистическом государстве... Но тогда в кружке Тугана царила единодушная и прекраснодушная уверенность в творческой силе марксизма. Я была одна из немногих, дерзавших задавать критические вопросы, сомневаться. Но где мне было спорить с такими книжниками. Для них все уже было доказанным, бесспорным. Они сыпали цитатами, перебирали страницы Маркса и Энгельса, точно это были волшебные мелодии Пушкина, ссылались на французов, изредка на англичан, больше всего на немцев, называли писателей, имен которых я никогда не слыхала...» [там же].

Я так много уделил внимания оценке А. Тырковой-Вильямс потому, что в советской литературе была распространена прямо противоположная точка зрения: П.Б. Струве и М.И. Туган-Барановский изначально не были марксистами. Думается все же, что истина где-то посередине. П. Струве и М.И. ТуганБарановский были искренне увлечены марксистской теорией, но не все в ней разделяли, причем в своих оценках марксизма даже расходились друг с другом. Если П.Б. Струве в дальнейшем развивался по пути апологии капитализма как несущего прогресс для России, то М.И. Туган-Барановский не прекращал поиски наиболее совершенной социалистической организации общества. Поэтому я не согла- сен с оценкой В.И. Ленина, что «легальные марксисты» были по существу «буржуазными демократами». Если это отчасти верно по отношению к П.Б. Струве (отчасти потому, что он явился автором «манифеста» российских социал-демократов, который был принят на I съезде РСДРП в 1898 г. в Минске), то совершенно неверно в отношении М.И. ТуганБарановского.

Разговоры, о которых вспоминает А. Тыркова-Вильямс, относились в основном к первой половине девяностых годов XIX в., но чем дальше к концу десятилетия, тем увереннее и осознаннее М.И. Туган-Барановский отходил от марксизма. Собственно, поиски своего пути в науке определились у него буквально с первых работ. Уже его первая большая статья «Учение о предельной полезности хозяйственных благ как причины их ценности» (1890) была не вполне марксистской [32, с. 192-230]. В ней рассматриваются две теории ценности: учение о предельной полезности Бем-Баверка, Визера, Джевонса и Менгера и трудовая теория ценности Д. Рикардо и К. Маркса. Следует отметить, что М.И. Туган-Барановский во всех своих работах употребляет термин «ценность», который использовался в советской литературе в первые 1012 лет после октября 1917 г., но в дальнейшем в научный оборот вошел термин «стоимость» [5, с. 214-225]. Фактически автор пытался примирить обе эти теории и считал, что теория предельной полезности не противоречит взглядам Рикардо или Маркса, но и не подтверждает учения этих экономистов о ценности. В дальнейшем основные идеи этой статьи были им развиты в работах «Теоретические основы марксизма» (1905) и «Основы политической экономии» (1909).

Строго говоря, была не вполне марксистской и магистерская диссертация М.И. Туган-Барановского «Промышленные кризисы в современной Англии, их причины и ближайшие влияния на народную жизнь», защищенная в Московском университете в 1894 году. Позднее ее содержание неоднократно перерабатывалось и дополнялось автором: при подготовке немецкого издания (Лейпциг, 1898; Йена, 1901), французского (Париж, 1913); наиболее полными были 3-е, «совершенно переработанное», (СПб., 1914) и 4-е (Пг., М., 1923) 
издания. С 3-го издания в 1997 г. было осуществлено и последнее, 5-е, издание в нашей стране [26]. В этой диссертации использовались идеи Ш.-Б. Сэя, Д. Рикардо, а также и К. Маркса. В частности, М.И. Туган-Барановский привлек теорию воспроизводства общественного капитала К. Маркса, изложенную во втором томе «Капитала». Он не случайно в качестве предмета исследования выбрал Англию, ибо она, по его мнению, является страной «классического капитализма». Вполне понятно, что «колебания промышленности, - замечал он, - были сильнее всего в той стране, в которой накопление капитала идет быстрее, то есть в Англии» [там же, с. 252]. Большое значение в происхождении и периодичности кризисов он придавал свободному ссудному капиталу. Теория М.И. Туган-Барановского в дальнейшем встретила критику со стороны руководителей германской социал-демократии, считавших основой кризисов «недопотребление трудящихся» [14, c. 38]. В России к позиции М.И. Туган-Барановского, однако, присоединились С.А. Первушин, В.Я. Железнов, И.М. Кулишер, В.К. Дмитриев и позже ученик М.И. ТуганБарановского Н.Д. Кондратьев. В частности, Н.Д. Кондратьев считал, что теория ТуганБарановского привела к складыванию научной школы. Работа М.И. Туган-Барановского «настолько ярко вскрывала природу капиталистического народного хозяйства в его целом и настолько в общем подтвердилась действительностью, что по справедливости доставила ему мировую известность, создала в этом вопросе целую школу, к которой с теми или иными оговорками примкнули столь видные экономисты западных стран, как Шпитгоф, Эйленбург, Поль, Шмоллер, Лескюр и др. Она породила целую литературу за и против нее. Даже и противники ее, как В. Зомбарт, признали ее чрезвычайным шагом вперед, высшей формой теории кризисов. Один из западных последователей Туган-Барановского А. Шпитгоф назвал его лучшим теоретиком экономической конъюнктуры, а книгу охарактеризовал, как первую научную монографию про кризисы» [9, с. 81; 13, с. 2-3]. Позже, уже в советское время, Н.Д. Кондратьев развивал идеи своего учителя [9]. Зарубежные экономисты XX в. (Элвин Хансен, Д. Кейнс, Пол
Сунзи, Ричард Кинерсли, Михаил Калецкий, Алек Ноув) чрезвычайно высоко оценили вклад М.И. Туган-Барановского в теорию кризисов [10].

Элвин Хансен, например, так понимал этот вклад: «Неоднократно говорилось, что в теории Адама Смита нет ничего нового, и однако его книга произвела настоящий переворот в экономической мысли. В некоторой степени то же самое можно сказать о ТуганБарановском в отношении теории делового цикла. Именно он положил начало новому подходу к изучению этой проблемы».

Отметим вклад М.И. Туган-Барановского в историю общественной мысли, который можно сформулировать в качестве следующих выводов:

1. М.И. Туган-Барановский был первым экономистом, доказавшим, что промышленные кризисы носят при капитализме периодический характер. «Промышленный цикл, теорию и объяснение которого я даю в этой книге, - писал он, - коренится в экономических условиях господствующей системы хозяйства - капитализма - и, представляя собой явление социального порядка, может сокращаться и растягиваться в известных пределах. Наличность этих пределов позволяет говорить о периодичности кризисов» [26, с. 57].

2. Он сформулировал теорию кризисов, или, как говорит его биограф Г.Н. Сорвина, «теорию капиталистической конъюнктуры», которая дала ему возможность прогнозировать наступление кризисов. На это обратил внимание М.И. Туган-Барановский в предисловии к третьему изданию своей книги в октябре 1913 г.: «Развиваемая в этой книге теория кризисов объясняет, какие факторы благоприятствуют увеличению и сокращению продолжительности промышленного цикла, а также вскрывают и движущие силы самого цикла. Поэтому не трудно, исходя из названной теории, формулировать признаки приближения промышленного кризиса, как это сделал, например, Брезигар... Таким образом, теория приобретает большое практическое значение: она дает возможность предвидения в чрезвычайно важной хозяйственной области» [там же, с. 58]. Эмиль Брезигар, на которого ссылается М.И. Туган-Барановский, в 1913 г. опубликовал книгу «Die Vorboten einer 
Wirtschaftskrise in Deutschland», в которой попытался установить признаки приближения кризисов, исходя из его теории [там же, с. 56]. Кроме того, в Париже в 1912 г. был учрежден по инициативе правительства «постоянный комитет для предвидения промышленных кризисов» [там же, с. 58].

3. М.И. Туган-Барановский наметил ряд признаков приближения кризиса: это цена железа, высота учетного процента. Поэтому он совершенно справедливо указывал на это в предисловии к 3-му изданию 6 октября 1913 г.: «...многое из этого, что я с таким трудом устанавливал в первом издании этой книги (то есть в 1894 г. - Авт.), стало теперь общим достоянием экономической мысли. Кто, например, теперь не знает, что цены железа, а отнюдь не цены хлеба (!) являются самым важным показателем фазисов промышленного цикла. Об этом говорит чуть ли не любой биржевой отчет, в этом убеждены теперь все люди практики... Но когда я выступил с этим тезисом 19 лет тому назад, то тезис этот не только не был общеизвестным, но был встречен как парадокс. Установил же я его чисто индуктивным путем, изучая движение цен железа в Англии за много десятилетий» [там же, с. 58].

4. Исследование М.И. Туган-Барановского показало, что капитализм никогда не умрет естественной смертью. Несмотря на существующие антагонизмы и кризисы, он внутренне способен к непрерывному развитию. За этот тезис потом его упрекали многие советские историки и экономисты. Что касается периодических промышленных кризисов, то они, считал М.И. Туган-Барановский, не являются «симптомом приближающейся смерти», а лишь острым и болезненным средством «самокорректирования пути развития со стороны капитализма» [30, с. 9].

В книге М.И. Туган-Барановского содержался еще один важный вывод об улучшении положения рабочего класса Англии к концу XIX в. по сравнению с первой половиной XIX века. Этот вывод был сделан на основе тщательного изучения статистических данных, которые, по мнению М.И. Туган-Барановского, «убедительно говорят, что действие промышленного застоя и безработицы на условия жизни массы английского населения сильно смягчено в новейшее время какимито причинами».

И далее он писал: «Важнейшими из этих причин следует признать общее поднятие экономического положения английского рабочего и рост тред-юнионизма» [26, с. 380 и след.]. Свои выводы М.И. Туган-Барановский иллюстрировал составленными им диаграммами на основе статистических данных правительства и прочих материалов.

Очевидно, что эта тенденция была характерна и для других капиталистических стран в той или иной мере. Заключение автора шло вразрез с одним из главных тезисов К. Маркса об обнищании пролетариата по мере развития капитализма [15]. Отметим здесь, что этот вывод М.И. Туган-Барановский высказал раньше на четыре года, чем немецкий социал-демократ Э. Бернштейн в своей знаменитой книге «Предпосылки социализма и задачи социал-демократии» (1898), которая считалась манифестом ревизионизма.

Этот вывод отвергался тогда марксистами, в том числе К. Каутским [38], Г.В. Плехановым и В.И. Лениным.

Я учился на истфаке Саратовского университета в 1966-1971 гг., но даже тогда наши профессора нам говорили об абсолютном и относительном обнищании пролетариата в капиталистических странах. В этом же духе был написан и самый популярный вузовский учебник Брегеля «Политэкономия капитализма». Насколько мне известно, против этой марксистской теории обнищания пролетариата выступал в СССР только один экономист академик Варга [3]. Этот спор М.И. ТуганБарановского и Э. Бернштейна с ортодоксальными марксистами завершился победой первых только в конце XX века.

Но вернемся в 90-е годы. После защиты магистерской диссертации М.И. Туган-Барановский, выступая против народников в защиту исторического материализма и по вопросу о роли личности в истории, отказывается от использования марксистских терминов и употребляет свои $[7 ; 22 ; 27 ; 33]$. Вместо «производительных сил» он говорит о «материальных условиях», «производственные отношения» заменяет «хозяйственными», «надстройку» трактует как «социальную среду» и т. п. Позже в работе «Очерки из новейшей 
истории политической экономики и социализма» (1903) М.И. Туган-Барановский будет подчеркивать преимущество своих терминов над терминами К. Маркса. Он обвинит марксизм в социальном монизме, в абсолютизации роли производительности сил в историческом процессе. В то же время, по мнению М.И. ТуганБарановского, сами производительные силы оказываются зависимыми от социальной среды. Таким образом, получается замкнутый круг, который свидетельствует о недоказанности теории исторического материализма.

Но эти положения М.И. Туган-Барановский сформулировал в 1903 году. До 1899 г. его разногласия с марксизмом проявлялись в довольно завуалированной форме. Да и сама проблематика его исследований не создавала основы для такого открытого и специального разговора.

Докторская диссертация М.И. ТуганБарановского «Русская фабрика в прошлом и настоящем» (Т. 1), защищенная им в Московском университете в 1898 г., была крупным вкладом в развитие историко-экономической науки. Эта работа восемь раз переиздавалась в нашей стране (последний раз в 1997 г.) и за рубежом (Берлин, 1900; США, 1970). Причем в США «Русская фабрика» была издана в серии «Экономическая классика». Даже в самые тревожные тридцатые годы XX в., когда в нашей стране вышло ее седьмое издание, «Русскую фабрику» называли в «основном марксистским трудом». Правда, тогда, в 1938 г., чекист-генерал Агранов «посоветовал» моему отцу не получать гонорар за «антиленинскую работу М.И. Туган-Барановского», хотя, как сын, он имел на это право, и к тому же о самой книге высоко отзывался В.И. Ленин [11, с. 339,$460 ; 12$, с. 132].

В своей диссертации М.И. Туган-Барановский проследил генезис и развитие капитализма с XVII в. по конец XIX в. и высказал мысль о том, что Россия «страдает» не от развития капитализма, а от «недостатка его развития». Этот тезис позже повторил В.И. Ленин в работе «Две тактики социалдемократии в демократической революции», правда, без ссылок на его автора. Как и П.Б. Струве [20], М.И. Туган-Барановский подчеркивал: «Наша культурная отсталость уменьшается благодаря развитию того же капитализма... И поэтому наш прогноз та- ков: успехи русской капиталистической индустрии за последнее время являются только слабыми начатками того могущественного развития русского капитализма, которое предстоит в будущем» [29, с. 376-377].

Позднее, уже в советское время, П.Б. Струве и М.И. Туган-Барановского называли за это «буржуазными объективистами». Если это было в какой-то степени верно по отношению к П.Б. Струве, то оказывалось совершенно неверно по отношению к М.И. Туган-Барановскому. В отличие от В.И. Ленина, он считал, что Россия не готова для перехода к социализму, и этот тезис он весьма глубоко обосновал в дальнейшем.

В 1899 и 1900 гг. М.И. Туган-Барановский опубликовал две статьи с критикой марксизма [25]. В них он отвергал сформулированный К. Марксом (в III-м томе «Капитала») закон тенденции нормы прибыли к понижению. Этот закон, по его мнению, противоречит фактам и является мнимым. М.И. Туган-Барановский усматривал противоречие между II-м и III-м томами «Капитала». Примерно в это время (19 мая 1899 г.) он писал социал-демократу А.Н. Потресову: «Странное, право, мое положение. Одни меня ругают за ортодоксальность, а другие за то, что я не настоящий марксист. Так, я недавно узнал, что многие правоверные марксисты очень озлоблены против меня за мою статью в «Архиве» ${ }^{1}$. Статья в майской книжке «Научного обозрения» озлобит, наверное, еще больше. Но что же делать? Для меня ясно, как дважды два, что конструкция Маркса несостоятельна. Тем не менее, огромное большинство признает, что я говорю сущий вздор. Это, разумеется, право каждого, - в том же письме говорит М.И. Туган-Барановский и далее делает очень любопытное и проницательное заключение: - Но следовало бы, мне кажется, строго различать разногласия в вопросах общественных и разногласия в вопроcax чисто научных. Я понимаю, что можно возненавидеть человека за первое, но за последнее, казалось бы, ненавидеть нельзя. А между тем у нас совсем не умеют различать эти две области» [19, с. 44-45].

Последнее высказывание как бы предвосхищает споры 30-50-х годов по научным проблемам. 
В работах, опубликованных уже в начале $\mathrm{XX}$ в., в полтавский период его жизни и позже, он пытался выработать свой взгляд на проблему социального идеала и способов его достижения. Согласно позиции М.И. Туган-Барановского, капитализм не мог умереть естественной смертью, и периодические промышленные кризисы были своеобразным способом исправления капиталистического общества.

Но при всем том он до конца своих дней оставался социалистом, в отличие от П.Б. Струве, который, как едко выразился Д.Н. Овсянико-Куликовский, последовательно переходил «от одной немецкой доктрины к другой» (цит. по: [24, с. 1]). Это обстоятельство и обусловило в конце концов расхождение М.И. Туган-Барановского с П.Б. Струве. Д.Н. Овсянико-Куликовский верно подметил, что М.И. Туган-Барановский от марксизма «ортодоксального» и «еретического» прямо перешел к самостоятельному творчеству, и в его книгах и статьях «современная социалистическая мысль получила глубоко оригинальное выражение» (цит. по: [там же, с. 1-3]). Уже с начала XX в., пытаясь отыскать совершенную модель общественного устройства, он основательно занимался изучением различных социальных теорий, в том числе и социалистических. Этому были посвящены многие его работы: от «Очерков...» (1901-1903) до «Социализма, как положительного учения» (1918). В них он отрицал претензию марксизма на научное социальное предвидение и доказывал, что идеи А. Сен-Симона, Ш. Фурье, Р. Оуэна и других, так называемых социалистов-утопистов, являются не менее научными, чем проекты К. Маркса и Ф. Энгельса.

В литературе часто высказывается мнение, что П.Б. Струве и М.И. Туган-Барановский испытали влияние бернштейнианства. Мне же кажется, что многое из немецкого ревизионизма они даже предвосхитили и скорее шли в своих исследованиях разными путями, испытав разочарование в марксизме.

От марксизма и тем более от большевизма М.И. Туган-Барановского отталкивала теория классовой борьбы и неверие в близкий крах капитализма, хотя он полагал, что капитализму будет нанесен удар, но это произойдет на определенном высоком уровне развития экономики и производительных сил. Кроме того, он критиковал марксизм с этических позиций, и я полагаю, что именно с этим была сопряжена его высокая оценка А. де Сен-Симона, Ш. Фурье и Р. Оуэна. С этим также был связан его интерес к философии Э. Канта. «У меня, - писал он П. Струве в 1901 г. из полтавской деревни, - складывается свое собственное философское мировоззрение, в основе которого лежит кантовское учение об идеальности пространства и времени; по-моему, сам Кант не вполне понимал значение этого своего гениального учения и не сделал всех выводов, которые из него проистекали» [17].

К сожалению, эту свою мысль М.И. Туган-Барановский полностью не расшифровал. Видимо, он собирался сделать это в перспективе. «Меня очень интересует философия, делился он с П. Струве примерно в 19021903 гг., - но писать на философскую тему я еще буду не скоро. Нужно еще выступить в качестве философа» [там же].

Последнее, вероятно, так и не состоялось. Но вслед за «Теоретическими основами марксизма» в 1909 г. он написал предисловие к русскому переводу книги К. Форлендера «Кант и Маркс: очерки этического социализма». По этому предисловию и по некоторым другим работам можно судить, что в мировоззрении И. Канта более всего его привлекала концепция верховной ценности человеческой личности. «Как верховная цель в себе, человек не может быть обращен в средство для других целей», - утверждал он [16], поэтому он также заинтересовался нравственными идеями Ф.М. Достоевского [23]. И уже с таких позиций понимания морали и этики судил о марксизме. И естественно, что это его суждение носило критический характер. Эта критика этических норм марксизма и особенно ленинизма кажется актуальной и убедительной в настоящее время с учетом нашего печального опыта. «Марксизм, - констатировал М.И. Туган-Барановский в 1909 г., отвергал необходимость этического оправдания социализма и, конечно, не без достаточных оснований. Дело в том, что вся система общественной философии марксизма проникнута принципиальным отрицанием этики. Внеклассовую этику марксизм признает предрассудком, а классовая этика есть внутренняя невозможность. И потому марксизм вполне 
последовательно ставит на место морали классовый интерес. Получается очень стройное социологическое построение, в котором для этики в собственном смысле слова места нет. И если на практике марксизм не в силах удержаться на этом принципиальном аморализме, то в теории он твердо стоит на этой позиции» (выделено мной. Авт.) [28].

На мой взгляд, в этих и особенно в выделенных мной словах заключена глубокая мысль, фактически содержится предвидение ленинизма и сталинизма. Ведь далее рассуждения В.И. Ленина о классовом характере морали привели к новым понятиям - «революционное правосознание», «революционная целесообразность», «диктатура пролетариата - это власть, не связанная никакими законами», и т. д., которые и послужили оправданием политических репрессий после Октября 1917 года.

Создавая свою модель «этического социализма», М.И. Туган-Барановский говорил, что если отбросить учение об абсолютной ценности человеческой личности, то все демократические требования «нашего времени окажутся простым разглагольствованием». Подобные утверждения шли вразрез с постулатами большевизма. Не случайно В.И. Ленин называл Ф.М. Достоевского «архискверным», а Н.И. Бухарин в 1913 г. отмечал, что в трудах М.И. Туган-Барановского «кроме этической болтовни», «которую всерьез принимать невозможно, мы ненаходим ровно ничего» [1, с. 182]. Н.И. Бухарина в этом вопросе поддержал другой «марксист» Л.Д. Троцкий [21, c. 241]. Не знаю, как Л.Д. Троцкий, но думаю, что Н.И. Бухарин позже, в ожидании расстрела в сталинской тюрьме, мог пересмотреть свое мнение о роли этики в общественном движении. Мне представляется поэтому, что с момента разрыва с В.И. Лениным, разрыва болезненного, но вызванного, безусловно, объективными обстоятельствами, М.И. Туган-Барановский с каждой новой работой все более отдалялся от К. Маркса. В 1902 г. он писал П. Струве: «Марксистская страничка нашего общественного развития, повидимому, приходит к концу - хотя нельзя, разумеется, не поручиться, чтобы наши «ортодоксы» не нашли себе подходящей среды для восстановления своего влияния, иболюди ужасно глупы, и нет такой глупости, которой бы они не поверили, если им хочется верить» [17]. В сущности, в это время он активно искал свой путь и, я думаю, нашел его. На этом пути было очень мало принципиальных соприкосновений с марксизмом.

\section{ПРИМЕЧАНИЕ}

${ }^{1}$ Исследование выполнено при финансовой поддержке РГНФ в рамках проекта № 12-01-00208 а «Изучение научного вклада М. И. Туган-Барановского в мировую общественную и экономическую мысль на рубеже конца XIX - начала XX вв.».

\section{СПИСОК ЛИТЕРАТУРЫ}

1. Бухарин, Н. И. Теоретическое примиренчество / Н. И. Бухарин // Политическая экономия рантье. - М. : Орбита, 1988. - 194 с.

2. Валентинов, Н. Встречи с Лениным / Н. Валентинов. - Вермонт : [Б. и.], 1953.-220 с.

3. Варга, Е. С. Очерки по проблемам политэкономии капитализма / Е. С. Варга. - М. : Политиздат, $1965 .-388 \mathrm{c}$.

4. Всемирная история экономической мысли / под ред. В. Н. Черковца. - М. : Мысль, 1989. - 760 с.

5. Зверяков, М. И. Некоторые аспекты теорий стоимости, ценности и кооперации М. И. Туган-Барановського / М. И. Зверяков, В. Г. Гринчук // Михаил Иванович Туган-Барановський (1865-1919): личность, творческое наследие и современность : сб. статей. - Донецк : Каштан, 2007. - С. 214-225.

6. Кареев, Н. И. Прожитое и пережитое / Н. И. Кареев. - Л. : Изд-во ЛГУ, 1990. - 382 с.

7. Кареев, Н. И. Старые и новые этюды об экономическом материализме / Н. И. Кареев. - СПб., 1896. $-305 \mathrm{c}$.

8. Кондратьев, Н. Д. Большие циклы конъюнктуры: доклады и их обсуждение в Институте экономики / Н. Д. Кондратьев, Д. И. Опарин // Проблемы экономической динамики. - М. : Экономика, 1989. $-58 \mathrm{c}$.

9. Кондратьев, Н. Д. Михаил Иванович ТуганБарановский / Н. Д. Кондратьев. - Петроград, 1923. $127 \mathrm{c}$.

10. Корнейчук, Б. В. Экономические воззрения М. И. Туган-Барановского / Б. В. Корнейчук. СПб. : Наука, 2008. - 335 с.

11. Ленин, В. И. Полное собр. соч. В 55 т. Т. 3 / / В. И. Ленин. - М. : Политиздат, 1971. - 570 с.

12. Ленин, В. И. Полное собр. соч. В 55 т. Т. 4 / В. И. Ленин. - М. : Политиздат, 1972. - 576 с.

13. Лескюр, Ж. Общие и периодические промышленные кризисы / Ж. Лескюр.-СПб., 1908. - 557 с.

14. Люксембург, Р. Накопление капитала Т. 1-2 / Р. Люксембург. - М. : Гос. издат., 1924. - 656 с. 
15. Маркс, К. Манифест коммунистической партии / К. Маркс, Ф. Энгельс // Избранные произведения. В 3 т. Т. 1. - М. : Политиздат, 1980. C. $95-138$.

16. ОР РГБ. Ф. 144. Карт. 8. д. 59. Л. 11.

17. РГАСПИ. Ф. 279. Оп. 1. Д. 963.

18. Советский энциклопедический словарь / гл. ред. А. М. Прохоров. - 2-е изд. - М. : Советская энциклопедия, 1983. - 1600 с.

19. Социал-демократическое движение в России / под ред. А. Н. Потресова и Б. Н. Николаевского. - М. ; Л. : Госиздат, 1928. - 97 с.

20. Струве, П. Б. Критические заметки по вопросу об экономическом развитии России / П. Б. Струве. - СПб. : Типография И. Н. Скороходова, 1894. - Вып. І. - 321 с.

21. Троцкий, Л. Д. Светские богословы и ванькина личность / Л. Д. Троцкий // Сочинения. - М. ; Л. : Госиздат, 1925. - Т. 3. - 356 с.

22. Туган-Барановский, М. И. Значение экономического фактора в истории / М. И. Туган-Барановский // Мир Божий. - 1895. - № 12. - С. 101-118.

23. Туган-Барановский, М. И. Нравственное миросозерцание Достоевского / М. И. Туган-Барановский // Вопросы обществоведения. - 1908. № 1. - С. $278-285$.

24. Туган-Барановский, М. И. Нравственное миросозерцание Достоевского / М. И. Туган-Барановский. - Одесса : Культурно-просветительная коммуна при Южно-русском потребительском обществе им. проф. М.И. Туган-Барановского, 1920. $-267 \mathrm{c}$.

25. Туган-Барановский, М. И. Основная ошибка абстрактной теории капитализма К. Маркса / М. И. Туган-Барановский // Научное обозрение. - 1899. - № 5. - С. 973-985.

26. Туган-Барановский, М. И. Периодические промышленные кризисы: История английских кризисов. Общая теория кризисов / М. И. ТуганБарановский. - 5-е изд. - М. : Наука, 1997. - 574 с.

27. Туган-Барановский, М. И. Письмо в редакцию / М. И. Туган-Барановский // Мир Божий. 1896. - № 5. - С. 117-120.

28. Туган-Барановский, М. И. Предисловие к русскому переводу книги / М. И. Туган-Барановский // Форлендер, К. Кант и Маркс. - СПб., 1909. $226 \mathrm{c}$.

29. Туган-Барановский, М. И. Русская фабрика в прошлом и настоящем / М. И. Туган-Барановский. - СПб., 1997. - 725 с.

30. Туган-Барановский, М. И. Социальные основы кооперации / М. И. Туган-Барановский. М. : Экономика, 1989. - 501 с.

31. Туган-Барановский, М. И. Трудовая ценность: теория прибыли // Научное обозрение. 1900. - № 3. - С. 607-633.
32. Туган-Барановский, М. И. Учение о предельной полезности хозяйственных благ как причины их ценности / М. И. Туган-Барановский // Юридический вестник. - 1890. - № 10. - С. 192-230.

33. Туган-Барановский, М. И. Экономический фактор и идеи / М. И. Туган-Барановский // Мир Божий. - 1896. - № 4. - С. 255-262.

34. Тыркова-Вильямс, А. На путях к свободе / А. Тыркова-Вильямс. - Нью-Йорк : Изд-во им. Чехова, 1952. $-429 \mathrm{c}$.

35. Украинская советская энциклопедия в 20 т. / гл. ред. М. Бажан. - 2-е изд. - Киев : УСЭ, 1984. Т. 11, кн. $1 .-520 \mathrm{c}$.

36. Франк, С. Л. Биография П. Б. Струве / С. Л. Франк. - Нью-Йорк : Изд-во им. Чехова, 1956. $-237 \mathrm{c}$.

37. Чумаченко, Н. Г. М. И. Туган-Барановский - украинский и российский экономист с мировым именем / Н. Г. Чумаченко // Михаил Иванович Туган-Барановський(1865-1919): личность, творческое наследие и современность : сб. статей. - Донецк : Каштан, 2007.- С. 25-45.

38. Kautsky, K. Krisetheorien / K. Kautsky // Die Neue Zeit. - 1902. - № 28-31.

\section{REFERENCES}

1. Bukharin N.I. Teoreticheskoe primirenchestvo [Theoretical spirit of consolation]. Politicheskaia ekonomiia rant'e [Political economy of the investor]. Moscow, Orbita Publ., 1988. 194 p.

2. Valentinov N. Vstrechi s Leninym [Meetings with Lenin]. Vermont, 1953. $220 \mathrm{p}$.

3. Varga, E.S. Ocherki po problemam politekonomii kapitalizma [Sketches on the issues of political economy of capitalism], Moscow, Politisdat Publ, 1965. 388 p.

4. Cherkovets V.N. (ed.) Vsemirnaia istoriia ekonomicheskoi mysli [The world history of economic thought]. Moscow, Mysl' Publ, 1989. 760 p.

5. Zveriakov M.I., Grinchuk V. G. Nekotorye aspekty teorii stoimosti, tsennosti i kooperatsii M.I. Tugan-Baranovs'kogo [Some aspects of M.I. Tugan-Baranovsky's theories of cost, value and cooperation]. Mikhail Ivanovich Tugan-Baranovs'kii (1865-1919): lichnost', tvorcheskoe nasledie i sovremennost' [Mikhail Ivanovich Tugan-Baranovsky (1865-1919): personality, creative heritage and present: articles.]. Doneck, Kashtan Publ., 2007, pp. 214-225.

6. Kareev N.I. Prozhitoe i perezhitoe [Lived through and experienced]. Leningrad, LGU Publ., 1990. $382 \mathrm{p}$.

7. Kareev N.I. Starye $i$ novye etiudy ob ekonomicheskom materializme [Old and new sketches of economic materialism]. St.-Petersburg, 1896. 305 p. 
8. Kondrat'ev N.D., Oparin D. I. Bol'shie tsikly kon"iunktury: doklady i ikh obsuzhdenie v Institute ekonomiki [Big cycles of an environment: reports and their discussion at Economy Institute]. Problemy ekonomicheskoi dinamiki [Problems of economic dynamics]. Moscow, Ekonomika Publ., 1989. 58 p.

9. Kondrat'ev N.D. Mikhail Ivanovich TuganBaranovskii. Petrograd, 1923. 127 p.

10. Korneichuk B.V. Ekonomicheskie vozzreniia M. I. Tugan-Baranovskogo [M.I.Tugan-Baranovsky's economic views]. St.-Petersburg, Nauka Publ., 2008. $335 \mathrm{p}$.

11. Lenin V.I. Polnoe sobranie sochinenii v $55 t$. [Complete works in 55 v.]. Moscow, Politisdat Publ., 1972, vol. 3. 576 p.

12. Lenin V.I. Polnoe sobranie sochinenii v 55 t. [Complete works in 55 vol.]. Moscow, Politizdat Publ., 1972, vol. 4. 576 p.

13. Leskur Zh. Obshhie i periodicheskie promyshlennye krizisy [General and periodic industrial crises]. St.-Petersburg, 1908. 557 p.

14. Liuksemburg R. Nakoplenie kapitala [Capital accumulation]. Moscow, Gosizdat Publ., 1924, Vol. 1-2.656 p.

15. Marks K., Engel's F. Manifest kommunisticheskoi partii [Manifesto of communist party]. Izbrannye proizvedeniia. $V 3 t$. [The chosen works. In 3 vol.]. Moscow, Politizdat Publ., 1980, vol. 1, pp. 95-138.

16. OR RGB. F. 144, kart. 8, d. 59, 1. 11.

17. RGASPI. F. 279, op. 1, d. 963.

18. Prokhorov A.M. (ed.) Sovetskii entsiklopedicheskii slovar' [Soviet encyclopedic dictionary]. Moscow, Sovetskaia entsiklopediia Publ., 1983. $1600 \mathrm{p}$.

19. Potresov A. N., Nikolaevskii B. N. (ed.) Sotsial-demokraticheskoe dvizhenie v Rossii [Social democratic movement in Russia]. Moscow, Leningrad, Gosizdat Publ., 1928. 97 p.

20. Struve P. B. Kriticheskie zametki po voprosu ob ekonomicheskom razvitii Rossii [Critical notes on the issue of economic development of Russia]. St.Petersburg, Tipografiia I. N. Skorokhodova Publ., 1894, iss. I. $321 \mathrm{p}$.

21. Trotskii L.D. Svetskie bogoslovy i van'kina lichnost' [Secular theologians and Vanka's personality]. Sochineniia [Works]. Moscow, Leningrad, Gosizdat Publ., 1925, vol. 3. 356 p.

22. Tugan-Baranovskii M.I. Znachenie ekonomicheskogo faktora [The meaning of economic factor]. Mir Bozhii [The Peace of God], 1895, no. 2, pp. 101-118.

23. Tugan-Baranovskii M.I. Nravstvennoe mirosozertsanie Dostoevskogo [Dostoevsky's moral outlook]. Voprosy obshchestvovedeniia [Issues of social science], 1908, no. 1, pp. 278-285.
24. Tugan-Baranovskii M.I. Nravstvennoe mirosozertsanie Dostoevskogo [Dostoevsky's moral worldview]. Odessa, Kul'turno-prosvetitel'naia kommuna pri Iuzhno-russkom potrebitel'skom obshchestve im. prof. M. I. Tugan-Baranovskogo Publ., 1920. 267 p.

25. Tugan-Baranovskii M.I. Osnovnaia oshibka abstraktnoi teorii kapitalizma K. Marksa [Main error of the abstract theory of capitalism of K.Marx]. Nauchnoe obozrenie [Scientific review], 1899, no. 5, pp. 973-985.

26. Tugan-Baranovskii M.I. Periodicheskie promyshlennye krizisy: Istoriia angliiskikh krizisov. Obshchaia teoriia krizisov [Periodic industrial crises: History of English crises. General theory of crises]. Moscow, Nauka Publ., 1997. 574 p.

27. Tugan-Baranovskii M.I. Pis'mo v redaktsiiu [A letter to editorial stuff]. Mir Bozhii [The Peace of God], 1896, no. 5, pp. 117-120.

28. Tugan-Baranovskii M.I. Predislovie krusskomu perevodu knigi [The preface to Russian translation of the book]. Forlender. K. Marx i Kant [Forlander. K. Marx and Kant]. St.-Petersburg, 1909.226 p.

29. Tugan-Baranovskii M.I. Russkaia fabrika v proshlom i nastoiashchem [Russian factory in the past and at the present time]. St.-Petersburg, $1997.725 \mathrm{p}$.

30. Tugan-Baranovskii M.I. Sotsial'nye osnovy kooperatsii [Social foundations of cooperation]. Moscow, Ekonomika Publ., 1989. 501 p.

31. Tugan-Baranovskii M.I. Trudovaia tsennost': teoriia pribyli [Labor value: profit theory]. Nauchnoe obozrenie [Scientific review], 1990, no. 3, pp. 607-633.

32. Tugan-Baranovskii M.I. Uchenie o predel'noi poleznosti khoziaistvennykh blag [The doctrine of marginal utility]. Iuridicheskii vestnik [Legal herald]. 1890, no. 10, pp. 192-230.

33. Tugan-Baranovskii M.I. Ekonomicheskii faktor i idei [Economic factor and ideas]. Mir Bozhii [The Peace of God], 1896, no 4. pp. 255-262.

34. Tyrkova-Vil'jams A. Na putiakh $k$ svobode [On ways to freedom]. New York, Chekhov Publ., 1952. $429 \mathrm{p}$.

35. Bazhan M. (ed.) Ukrainskaia sovetskaia entsiklopediia v 20 t. [The Ukrainian Soviet encyclopedia in 20 vol.]. Kiev, USE Publ., 1984, vol. 11, b. 1. 520 p.

36. Frank S.L. Biografiia P. B. Struve [P. B. Struvt's biography]. New York, Chekhov Publ., 1956. $237 \mathrm{p}$.

37. Chumachenko N.G. M. I. TuganBaranovskii - ukrainskii $i$ rossiiskii ekonomist $s$ mirovym imenem [M.I.Tugan-Baranovsky, Ukrainian and Russian economist of worldwide reputation]. Donetsk, Kashtan Publ., 2007, pp. 25-45.

38. Kautsky K. Krisentheorien. Die Neue Zeit. 1902, no. 28-31. 


\title{
M.I. TUGAN-BARANOVSKY AND HIS ATTITUDE TO MARXISM
}

\section{Tugan-Baranovsky Dzuchi Mihaylovich}

Doctor of Sciences (History), Department of Archeology and Foreign History, Volgograd State University

adsi@volsu.ru

Prospect Universitetsky, 100, 400062 Volgograd, Russian Federation

\begin{abstract}
In the article the author challenges the point of view widespread in the Soviet literature that M.I.Tugan-Baranovsky initially was not a Marxist. In his opinion, the Russian thinker at first was sincerely keen on Marxism, but divided not everything in it. Already in his first scientific article "About the value reasons"(1890) he made amendments to the theory of value of Karl Marx. Strictly speaking, his master thesis about industrial crises was not quite Marxist. In it he came to a conclusion that capitalism will not die a natural death and is internally capable to continuous development. However, doctoral dissertation of M.I.TuganBaranovsky "The Russian factory" (1898) was got generally by Marxist ideology. The scientist started open criticism of Marxism since May, 1899.

Further, at the beginning of the XX century he accused Marxism of a social monism, absolutization of a role of productive forces in historical process, underestimation of mental factors of social development, denied the law of tendency of rate of profit formulated by Karl Marx to fall and the impoverishment of the proletariat. The Russian scientist also sharply criticized Marxism from ethical positions and according to the author of this article this criticism of Marxist ethics and morals actually contained anticipation of Leninism and Stalinism. In fact, at the beginning of the XX century the scientist actively looked for his own way, and on this way there were very few basic contacts with Marxism.
\end{abstract}

Key words: Marxism, revisionism, socialism, Eduard Bernstein, narodniki (Russian Populists), "Legal Marxism". 